\title{
'It really is about telling people who asylum seekers really are, because we are human like anybody else': Negotiating victimhood refugee advocacy work
}

\section{Abstract}

This article explores how refugee advocates, and refugees themselves, manage social hostility towards refugees and migrants through their talk, specifically how this hostility is managed through orientation to the category 'victim'. Case studies from the publicity materials of four advocacy organisations, as well as the 'internal' talk of their staff, volunteers and beneficiaries collected via Narrative Biographical Interviews, are analysed using discourse analytic methods, specifically Membership Categorisation Analysis. This allows insight into the differing aspects of the organisation's talk and allows analysis of how orientation to the victim category is distributed and managed across the 'dialogical network'. This discourse analytic approach, sensitive to how members of the 'dialogical network' make hostile and sympathetic voices relevant features of their local talk and manage categorisations of refugees in often tacit ways, highlights a pattern of category change, where a reworking of the dominant modes of refugee representation performed by the organisations in their publicity materials is achieved by their members and beneficiaries. The category work negotiated by advocate and refugee informants rearranges the components of the helping relationship, centring the experience, voice and strength of asylum seekers/refugees, and decentres the objectives of the helping organisations - offering insights into new ways forward for refugee advocacy as a practice of solidarity beyond charity. 


\section{Keywords}

Advocacy, asylum seekers, category change, charity, de-centring, discourse, discourse analysis, humanitarianism, identity, membership categorisation analysis, migrant, narrative, refugees, solidarity, United Kingdom, victimhood

The rhetoric surrounding the so-called EU 'refugee crisis' has manipulated the figure of the refugee so heavily that it is simultaneously brought into the limelight while being distorted out of comprehension. It is not only those who are hostile towards refugees who employ such rhetorical distortions but also those who are sympathetic. The language used by organisations that exist to 'stake a claim' (Tyler, 2006) for refugees is analyti- cally important, having a direct relationship with political and humanitarian responses (Masocha, 2014; Turton, 2003).

Kirkwood (2017) explores the humanisation of refugees in Parliamentary debates in the United Kingdom, highlighting a gap in the literature on the dehumanisation of refu- gees (Goodman, 2005; Goodman and Speer 2007; Santa Ana, 1999). Kirkwood (2017) concluded that attempts to humanise refugees did not necessarily overcome the 'us' and 'them' binary (Lynn and Lea, 2003) and that 'the emphasis was on 'their' human nature and/or vulnerability in ways that deserve support and protection, and "our" human nature that consists of helping others and/or being able to sympathise'. Moreover, 'at least some forms of "humanisation" appear to reinforce paternalistic relations between those who need and those who provide asylum' (Kirkwood, 2017: 122). The attempts at humanising refugees achieved a moral status for the speakers that did not challenge existing power imbalances.

The death of Alan Kurdi saw a huge rise in support for refugees; people offered their homes, money and time volunteering in refugee camps alongside an uncharacteristic outpouring of sympathy from the media (Goodman et al., 2017). Bates (2017) describes a softening of attitudes towards refugees in UK polls following Alan Kurdi's death; how- ever, they continued to indicate that the majority of people in the United Kingdom remained opposed to accepting refugees into Britain. Goodman et al. (2017) analysed media coverage of the European 'refugee crisis' during 2015 exploring the shift in cate- gorisation, from 'refugee' to 'migrant' and the action orientation of this category work. What began as a 'migrant crisis' with people arriving by boat at European borders became 
a 'refugee crisis' following the death of Alan Kurdi and then a 'migrant crisis' again in response to the Paris terror attacks. This categorisation is not a simple reflection of events but is used to achieve discursive outcomes; 'refugees' are worthy of our sym- pathy, whereas 'migrants' are a security issue.

Nightingale et al. (2017) problematise sympathetic talk arguing that the 'hostile- affective discursive environment towards asylum seekers enforces an ambivalent pater- nalistic constraint on sympathetic repertoires, which undermines potency for political change and merely produces a recognisable discomfort that cloaks power and privilege' ( $\mathrm{p}$. 145). They found that while informants were able to express sympathy with refugees in a way that confirmed the informants humanity (Kirkwood, 2017), the nature of this sympathy managed a 'sanitised expression of exclusion' (Nightingale et al., 2017: 138) 
whereby national identity and the nation-state remained valid precursors for the material exclusion of refugees. Although the informants spoke of the 'heartbreaking' impact of the death of Alan Kurdi, they struggled to transform that into political action or genuine refuge.

Employing conversation and discourse analytic methods, this article explores how refugee advocates, those whose work is to present sympathetic representations of refu- gees, negotiate the identities of refugees in their everyday work. Specifically, it explores how they manage these identities against common hostile frames of refugee representa- tion (Bloch and Schuster, 2002; Goodman and Speer, 2007; Lynn and Lea, 2003; Sales, 2002) through counter-narratives (Leudar et al., 2008). This article extends the work carried out by Leudar et al. (2008) in which the 'action orientation' of talk about refugees and migrants was analysed. They concluded that talk about refugees was characterised and made cohesive through a set of 'hostility themes'. These thematically organised hostilities were made relevant by speakers as features of the setting in which refugees and migrants live and put their activities 'under description' in a way that justified their exclusion. They included themes such as refugees/migrants have infectious diseases, cannot look after their children and are criminals (Leudar et al., 2008). These hostile themes did not go unchallenged. Informants who were sympathetic towards refugees, and refugee informants, challenged the basis of this hostility by constructing biographi- cal contrasts 'that made the grounds of contemporary hostile rejections false and irrele- vant to themselves' (Leudar et al., 2008: 87).

This sequencing of hostile and sympathetic voices can be conceptualised as a 'criti- cism-defence-structure' (Nekvapil and Leudar, 2006). By employing the 'dialogical net- work' analytical framework (Leudar and Nekvapil, 2004), the analysis is able to 'to ascertain the way refugee identities are contested and formulated in ongoing and distributed conflict' (Leudar et al., 2008). The notion of dialogical network presupposes that identity negotiations in situ do not manifest as discrete or isolated events, rather they are 'inter-textual'. Participants orient themselves to the exophoric circumstances of their talk and are 'sometimes involved in two "conversations" at the same time - with those pre-sent and those absent' (Leudar and Nekvapil, 2004: 248). The notion of dialogical net- work sensitises us to the possibility that hostilities towards refugees voiced in other times and places frame the talk of those who are sympathetic and that of refugees themselves. Leudar et al. (2008) concluded that the internalisation of these themes by refugees has negative 
consequences for well-being.

This article extends that work and explores the category work done by refugee advo- cacy organisations, their members and their beneficiaries in relation to the problem of hostility. Leudar et al. (2008) among others (Judge, 2010; Lynn and Lea, 2003; Pupavac, 2008; Van Dijk, 2000) have demonstrated how these hostilities are countered with 'sym- pathetic' representations oriented to the themes of passivity and victimhood. This article is specifically concerned with the nuances and possibilities of the membership category 'victim' and how it is oriented towards in advocacy talk, and the talk of refugees, as a method of refuting hostility. This specific orientation in advocacy talk is important from an analytic and practice perspective as it is widely criticised for depoliticising refugees and limiting the potential for political change and solidarity (Judge, 2010; Malkki, 1996; Nyers, 2006; Pupavac, 2006, 2008). 
Barbara Harrell-Bonds' controversial Imposing Aid (1986), alongside classic studies of migrancy, such as Liisa Malkki's 'Speechless emissaries: refugees, humanitarianism and dehistoricization' (1996), has dealt with the dehumanising and depoliticising effect of humanitarian language. Malkki (1996) observes, '... one important effect of the bureaucratized humanitarian interventions ... is to leach out the histories and the poli- tics of specific refugees' circumstances. Refugees stop being specific persons and become pure victims in general' (p. 378). Monitoring of these forms of representation is embed- ded in international humanitarian practice. The Code of Conduct that governs members of the International Red Cross and Red Crescent Movement, and other disaster relief non-governmental organisations (NGOs), dictates that organisations 'shall portray an objective image of the disaster situation where the capacities and aspirations of disaster victims are highlighted, and not just their vulnerabilities and fears' (ICRC, 1992).

This article uses discourse analytic methods to explore the nuances of hostility and counter-narratives in the important and growing area of refugee advocacy work. Does orientation to the category of 'victim' cast refugees as vulnerable dependants (Judge, 2010), reproducing 'paternalistic relations' (Kirkwood, 2017) that 'undermine[s] potency for political change' (Nightingale et al., 2017), promoting a 'sanitised expression of exclusion' (Nightingale et al., 2017)?

Nightingale et al. (2017) questioned whether the public nature of the talk in their study (radio interviews) limited how far people were willing to extend sympathy to refugees, as speakers must 'retain common ground with the audience' (p. 141). Similarly Lynn and Lea (2003) argue that 'those with greater social or political power are more inclined per-haps, to play a "political game"; with greater eye to the rhetorical effect their talk might have' (p. 430). Here, the analysis will focus on how hostility towards asylum seekers/refu- gees, and the counter-category 'victim', is managed by advocates on an organisational level via publicity materials and by advocates and refugees themselves in everyday talk.

In summary, victimisation is a common trope (Judge, 2010) characteristic of 'sympa- thetic representations' (Pupavac, 2008) of refugees; these counter biographical represen- tations tackle hostility through 'tacit acknowledgement' (Leudar et al., 2008) of exclusionary hostile themes. Refugee charities and humanitarian projects have been criticised for 'leaching out' the identities of refugees in order to present them as 'pure victims' (Malkki, 1996). These sympathetic representations of refugees have been criti- cised for reproducing 'sanitised expressions 
of exclusion' (Nightingale, 2017: 138) that do little to promote concrete, sympathetic political action. Yet they do establish common ground with the public, an essential task for advocacy projects. As Tyler (2006) points out, there is a tension between

the urgency of staking a political claim' (on behalf of asylum-seekers) and the need to reflect critically on the language in which those claims are made, is a tension that we should not seek to alleviate but should encourage and explore in critical theoretical practice. (p. 199)

This article aims to explore that tension within four advocacy organisations in the North West of the United Kingdom. How are these common tropes of refugee representa- tion taken up by members of advocacy groups and their beneficiaries - is this a live issue for members of the dialogical network? Sacks (1979) in his seminal article 'Hotrodder: 
a revolutionary category' demonstrated that non-compliance with a category, and its usage, is an act of resistance. This article is concerned with how participants of asylum seeker/refugee advocacy organisations (advocates and asylum claimants) negotiate hos- tility towards refugees/themselves via the membership category 'victim' and how the 'victim' category is distributed, oriented toward and manipulated across the dialogical network. Are 'asylum seekers/refugees' presented as 'pure victims in general?' (Malkki, 1996). What other uses of 'victim' are possible? This article aims to explore 'victimhood' as a dynamic category around which advocates and refugees could narrate various pos- sibilities for themselves and others.

\section{Method}

The publicity materials of four refugee advocacy organisations in Manchester are ana- lysed in order to establish the hostility-defence sequences (Leudar et al., 2008 Nekvapil and Leudar, 2006) characteristic of their public facing talk. Narrative Biographical Interviews are conducted with members of these organisations in order to establish how this category work is extended across the dialogical network, exploring the internal talk of staff and volunteers and the pickup of these themes by their refugee beneficiaries. Immigration Legal Aid Manchester (ILAM) provides independent immigration and asy- lum legal advice; Refugee Act Now (RAN) is a UK-based refugee charity providing front-line advice for asylum seekers/refugees; Against Immigration Controls (AIC) is a radicalleft, against borders, activist group; Asylum Seeking Women Unite (ASWU) is a self-organised group of women asylum seekers. These various organisations collaborate closely with each other; their volunteers often overlap, as do their beneficiaries.

Publicity materials including flyers, posters, websites and publications were collected from the four organisations. Narrative Biographical Interviews (Wengraf, 2001) were conducted with staff and volunteers and with asylum seeking and refugee clients/mem- bers. The literature suggests that hostility is often implicit and banal, 'tacitly acknowl- edged' rather than explicitly dealt with (Leudar et al., 2008); as such, the analytic methods have to be sensitive to this. The research aims were not revealed in the recruiting and interviewing of participants so as not to foreground the relevancy of 'hostility' or 'vic- timhood', rather to observe how hostility and counter-narratives are situated spontane- ously. All of the interviews are conducted by the author and followed the Narrative Biographic Interview format (Wengraf, 2001). Interviewees were asked 
to speak about their experiences of coming to the United Kingdom and of accessing advocacy services or of working in refugee advocacy services.

A micro approach to discourse analysis grounded in ethnomethodology (Garfinkel, 1967) is utilised to explore how members negotiate category use. Using this approach, discourses are better thought of as 'occasioned collections of occasioned matters, rather than something that is objective and independent of the setting' (Leudar and Antaki, 1996, in Leudar et al., 2008: 189) as in discursive psychology (Edwards and Potter, 1992). A central analytic concern is what contexts people make relevant and how they reflexively put actions and expressions under description (Anscombe, 1957). Hostility themes are analysed as features of the setting, and category use puts actions and expres- sions under description in specific action-oriented ways. 
Membership Categorisation Analysis (MCA; Leudar et al., 2004) is employed for detailed analysis of talk that foregrounds the category work done by participants in the dialogical network. MCA is concerned with the social and linguistic resources people use to establish identities in interaction. This article is concerned with how people manage themselves (and others) as members of particular social categories and how they manage problems, as features of their settings (i.e. hostility) related to these categories. Specifically, this article addresses how people negotiate and manage category conflict and change (see Sacks, 1979), using the lens of dialogical network 'to ascertain the way refugee identities are contested and formulated in ongoing and distributed conflict' (Leudar et al., 2008). As Leudar and Nekvapil (2008: 190) have demonstrated, 'cohesion of dialogical networks can be also achieved by the coordination of the participant's membership category work' (Leudar et al., 2008).

The materials were selected on the basis that they dealt explicitly with the identities of refugees/asylum seekers and, grounded in the conclusions reached by Leudar et al. (2008), were analysed for their orientation, implicitly or explicitly, to situated or generalised hostil- ity towards refugees in order to establish that such a hostility-defence structure (Leudar et al., 2008; Nekvapil and Leudar, 2006) was a relevant feature of the discursive setting. All of the materials were then analysed against this ground to establish the emergent themes and counter-narratives via which the hostility is negotiated. Materials were selected on the basis that they oriented implicitly or explicitly to the victimisation of refugees - emerging (and analysed) as a component of the hostility-defence structure. The first extract demon- strates how hostility enters the talk of advocacy organisations and how it is managed via their counter-representation of refugees. The analysis then explores how organisations, their members and beneficiaries orient to the membership category 'victim' and how this orientation is distributed, managed and reproduced across the dialogical network.

This study was granted ethical approval from the University of Manchester Psychology Department. Pseudonyms are used for all organisations and participant names to main- tain confidentiality.

\section{This study}

\section{Managing hostility}

Leudar et al. (2008) observed that orientations to hostility themes are not always voiced explicitly. In some cases, members use reported speech to quote the arguments made by their opponents, explicitly recruiting their 
words to formulate a defence (Antaki and Leudar, 2001). However, in many cases, the hostility provides the field against which the meaning of the talk can be more fully understood. This orientation is often implied, and this in itself is an important analytical observation that highlights the pervasiveness of hostility and its potential to frame spatio-temporally distributed instances of talk. Leudar et al. (2008) conclude, 'the sequential structure "hostility theme-defence" was implicit (hostility themes do not have to be explicitly voiced, they seem omni-relevant)' (p. 207). The omni-relevance of 'hostility themes' is evident in the materials that follow; at times voiced in the style of reported speech, at others hearable as constituting the exophoric circumstances of the talk against which specific meanings are generated. 
The following extract is taken from the publicity materials of RAN and demonstrates how hostility enters the materials and how it is reworked by the organisation in order to rebut it. Mobiles, Money \& Mayhem. The Facts and Fibs About Asylum is a pamphlet produced by RAN, designed to counter myths about refugees. The following extract deals with the 'myth' that asylum seekers and refugees are criminals:

\section{Extract 1}

"Most asylum seekers and refugees are criminals"

Aren't there always a couple of rotten apples to spoil the barrel, a couple of bad eggs

in every community that ruin it for the rest of us by bringing crime to our streets?

4 It's the same story worldwide and that includes the asylum seeker and refugee

5 community too. But you'll be pleased to hear that the entire asylum and refugee

6 population aren't out raping and pillaging their way round the UK.

A report published by the Association of Chief Police Officers found no evidence

8 that asylum seekers are more likely than anyone else in the community to commit

criminal offences, and that asylum seekers are more likely to be the victims of crime

0 than the perpetrators.

The organisation uses reported speech to make relevant the voice of the hostiles (Antaki and Leudar, 2001). Asylum seeking is put under a new description by the organi- sation. Several possible categories are set up here to which asylum seekers and refugees might belong. In line 1 , the view that asylum seekers/refugees are 'criminals' is intro- duced. In lines 2-4, asylum seekers/refugees are negotiated as incumbent of a diverse community like any other. However, in line 9, it is proposed that asylum seekers are particularly vulnerable to crime. The organisation explicitly reverses hostile social cate-gorisations, foregrounding a dichotomy along which asylum seeker identities are man- aged, 'criminal vs. victim', (Van Dijk, 2000) while endorsing the latter. The effect is to remove the significance of 'criminality' from the asylum seeker/refugee community: 'aren't there always a couple of rotten apples to spoil the barrel?' (line 2 ); equating the 'asylum seeker and refugee community' (lines 4 and 5) 
with 'every community' (line 3) can be understood as an attempt at humanising refugees.

In lines 9 and 10, the organisation formulates its own generalisation 'asylum seekers are more likely to be victims of crime'. As was the case with the 'extreme case formula- tion' in line 1, it is rhetorically more powerful than stating 'some asylum seekers aren't criminals, sometimes they are victims of crimes' (Pomerantz, 1986), and here, the statement is backed up by the voice of the Association of Chief Police Officers. The organisation does not attack the sentiment that some refugees might be criminals; rather, it challenges the exaggerated style of the hostility. It does this by positioning refugees as 'just like us' and by recruiting the authoritative voice of the police (see Antaki and Leudar, 2001). The organisation maintains an 'us' and 'them' distinction (Lynn and Lea, 2003) that groups 'asylum seekers' together in a 'community' to whom certain characteristics and experiences are ascribed; they are at once just like the regu- lar community who may or may not be 'bad eggs' while also being vulnerable to crime due to their asylum seeking status. The organisation orients itself towards 'hostility themes' (Leudar et al., 2008) constructing a biographical contrast that makes the hos- tility inaccurate and implausible. 
It is apparent then that 'disputing the normative hostile position towards asylum seek- ers requires considerable discursive labour' (Kirkwood et al., 2013, in Nightingale et al., 2017: 138). The following extracts explore further how the organisations manage hostil- ity through tacit acknowledgement of hostile themes and negotiate refugees as incum- bent of the category victim, first in their publicity materials and then in the talk of staff and volunteers.

\section{Doing being victim}

The following case studies demonstrate how the 'major status' (Hester and Eglin, 1997) 'victim' is achieved in orientation to this hostility. Steimel (2010) summarised in her 2010 article on refugee 'human stories' that 'the victim story clearly dominates as the preferred narrative for refugees' ( $\mathrm{p}$. 226). Crawley et al. (2016) in an extensive analysis of British media coverage of migrant issues summarise that by representing migrants as victims, we fail to acknowledge the varied experiences of migrants in the United Kingdom and that 'the experiences of migrants are largely represented as "exceptional" rather than as a normal part of contemporary British society' (p. 6). To ascribe a person, or group of people, to the category 'victim' is a complex 'accomplishment'; this article explores how the organisations achieve this 'victim' status for refugees, first in their publicity materials and then in the talk of their staff and volunteers.

\section{Publicity materials}

The following extract is taken from the 'case studies' section of the ILAM website, which promotes the organisations' success stories.

\section{Extract 2}

1 Josephine was only 6 years old when both her parents were killed in Angola's civil

2 war. She is from Cabinda, which is a part of Angola which is seeking independence

3 and has been the scene of a long running conflict as a result. Josephine cannot

4 remember exactly what happened to her parents, but she thinks they were shot by the

5 police. She was taken in by an orphanage run by a priest after the death of her 
6 parents. When Josephine was 14 years old the priest asked her and the other orphans

7 to help him deliver opposition political leaflets. She did this. Not long afterwards,

8 the orphanage was attacked by the police and burnt down. Josephine and the other

9 children escaped with the help of the priest. The priest realised that Josephine was in

10 danger and made arrangements for her to be brought to the UK. The man who

11 brought her abandoned her outside the Home Office in Liverpool.

The organisation foregrounds Josephine's youth and, therefore, her unquestionable innocence. Judge (2010) problematises the overinfantilised representation of asylum seekers/refugees noting that advocates 'reliance on the discourse of children's rights and its "solutions" may have effects that place certain asylum seekers and refugees in the UK in challenging positions due to their age and gender' (p. 5).

Josephine's narrative can be analysed with this work in mind. Judge (2010) argues that 'a powerful western ideal of childhood as a time of innocence and safety free from 
politics or responsibility ... underpins children's rights thinking' (p. 9). The foreground- ing of Josephine's youth constructs a moral discrepancy based on her primary identifica- tion as a (naïve and innocent) young girl and the activities she is narrated through (violence, persecution and abandonment). The foregrounding of her youth and down- playing of her agency in coming to the United Kingdom and in the political action that precedes it makes it possible for her to be viewed as an innocent victim rather than an active participant in the anti-government conflict, to whom the reader/audience may deem this experience/treatment more acceptable. Josephine is situated in the 'victim' frame via a foregrounding of her passivity (Van Dijk, 2000) which makes it impossible for her to be heard as incumbent of the alternative hostile framing made available for migrants in the press, 'villain' (Crawley et al., 2016).

The impact of the death of Alan Kurdi on positive media reporting in the United Kingdom and international humanitarian responses to refugees is understandable through this lens and so is the failure for this reaction to extend to calls for systemic and political change. As Crawley et al. (2016) point out, 'giving a voice to migrants as victims relied too heavily on emotional reactions which do not necessarily contribute to a balanced and well-informed public and political debate on migration, nor to good policy making' (p. 32). Incumbency of the category 'victim' works to (implicitly) deny hostility towards refugees but is limited in what it achieves for Josephine and for refugees in general. As Crawley et al. (2016) argue, focusing on vulnerability undermines the contribution that migrants can make and exacerbates fears that migrants will become a burden on public services. More importantly, it denies Josephine, and other victims of civil war, a voice. We do not know how Josephine feels about the conflict and the loss of her parents or what she wants for herself in the United Kingdom.

How is this status managed for adults? In the following extract, suffering is dealt a further level of granularity (Zhang and Schwartz, 2011), perhaps requiring more 'discur- sive labour' (Kirkwood, 2017) to have an 'adult' heard as a 'pure victim' (Malkki, 1996). This extract is taken from the campaigns section of the ASWU website and is a call for support for Sara's anti-deportation campaign:

\section{Extract 3}

2 Sara's life all changed the day her pharmacy in Uganda was raided by soldiers. 
3 She was taken to a 'safe house', where she was kept in a tiny cell and repeatedly

4 raped and tortured whilst facing interrogation. Although freed after several days

5 she was again to face the same ordeal when the soldiers came back to find her and

6 her husband. Forced to flee Uganda she came to England where despite this

7 continued persecution, her asylum case has been refused.

8 Even a medical report stating that 'the medical evidence gives strong support for

9 the history of repeated rapes leading to life threatening gynaecological

10 complications necessitating major surgery'. Moreover, Amnesty, Human Rights

11 Watch and the government themselves all attest to the use of rape against women

12 in Uganda as a means of coercion.

13 Sara claimed asylum in 2003 and was forced into destitution in December 2004

14 when her appeal was turned down. Sara lived rough for many months. She now

15 stays with an English woman and lives off Red Cross parcels, while she tries to 
16 find a solicitor to take up her case and put in a fresh claim using new evidence that

17 she has been able to recently gather.

18 Sara also has had no news about her husband and children and prays they are safe.

A 'culture of disbelief' is a hostility tacitly acknowledged and defended in this extract. The intersection of racism and patriarchy arguably makes it particularly hard for women asylum seekers to be heard as victims and subsequently puts more pressure on them to divulge the details of their attacks. Lee's (1984) conversation analytic study of news coverage of sexual assault reminds us that 'rape is seeable as a morally unjusti-fied act but the victims of rape are always monitorable for their innocence and for the degree of that innocence' (p. 72).

So, it seems that to be recognised as a victim of rape, a victim per se, and a genuine asylum seeker, is a complex achievement, contingent on the constructability of inno- cence. As such, the political history of the events is noticeably absent; we are not told why her pharmacy was raided. Rather, the events described in lines 2-4 are introduced as de-contextualised abuses. This removal of the political context situates the abuse as unwarranted; as far as the reader knows, Sara is an ordinary woman working in a phar- macy. This foregrounding of her 'ordinariness', her lack of agency and the degree of her suffering intersect to make her hearable as 'victim', challenging the disbelief that is voiced implicitly by the Home Office (who refuse her). She is an ordinary woman in extraordinary circumstances.

At this point, the extent of Sara's trauma is 'zoomed in on' (see Schegloff, 2000; Zhang and Schwartz, 2011); due to her repeated rapes, she has 'life threatening gynaecological complications necessitating major surgery' (line 9). The truth behind her story is upheld by an authoritative voice, and the nature of her suffering is exposed in the most personal way. Her most intimate scars, of invasive and violent attacks, are used as evidence (line 16). The power of medicine and physically visible suffering legitimate her suffering. While foregrounding Sara's victimhood, ASWU collude with the epistemic medical authority that demands physical signs of suffering over personal accounts and expressions (Pupavac, 2008). As Nussbaum states, compassion is ' a complex emotion including such cognitive beliefs as that suffering of the other is serious, and that the suffering person does not deserve the pain' (Nussbaum in Hiojer, 2004). The action orientation of this text is arguably to legitimate and 
foreground Sara's suffering and herinnocence.

In their publicity materials, advocacy organisations orient themselves towards 'hostil- ity themes' along which asylum seekers/refugee identities are organised. Their talk can thus be understood as framed in part by the hostility, with consequences for how asylum seekers/refugee identities are managed locally. This analysis is not complete without the inclusion of the voices of the members of these organisations. This article is concerned with how the distributed sequence hostility-defence (Leudar et al., 2008) permeates advocacy discourses and how this framing influences how asylum seeker/refugee identi- ties are negotiated by asylum seeker/refugee advocates and asylum seekers/refugees themselves. I am interested in how the talk of advocates compares to the narratives pre- sented in the publicity materials. The staff, volunteers and students who make up these organisations have to bring the policies and positions outlined by the organisations into practice; how do they manage this? 


\section{Advocates}

The following extract is taken from an interview conducted with Hayley, a campaigner with the organisation AIC. Hayley is a founding member of the organisation, and as a lay member of the dialogical network, she orients towards the 'tension in staking a political claim' (Judge, 2010) that is evident in the publicity materials:

\section{Extract 4}

$1 \quad \mathrm{H}$ : So the first- the first anti-deportation campaign I'd say I was centrally involved

2 in in a political sense rather than as a supporter would be the $\mathrm{xxx}$ family

3 defence campaign, I've given you lots of materials about that, and if you want to

4 ask me any more than I say then that's fine. In a way that- that was a really good

5 example of why you never win an anti-deportation campaign even if the people

6 are given, as they were, ultimately, um:: right to remain because it's just so

7 disgusting that you have to have it to start off with and one of the tensions in that

8 and many other campaigns is the tension about how much you assert that people

9 are entitled to stay here because it's a basic human right and how much you

10 campaign on the particular vulnerabilities of [that

11 L: ok]

$12 \mathrm{H}$ : that- person or that group of people. Um m- my late friend $\mathrm{xxxx}$ said that he

13 realised how completely brutalised he'd been by the system, he was a barrister,

14 when somebody once told him she'd been raped and his first response was 'oh

15 good I can use that"

16 L: right $\mathrm{OK}$

$17 \mathrm{H}$ : and i- i- that isn't meant any disrespect to him or her but it's just that that's

18 how awful it was 
Hayley demonstrates that Tyler's 'tension' (2006) is a live issue for members of the dialogical network and makes this relevant as an exophoric circumstance of the inter- view. This tension emerges around 'how much you assert that people are entitled to stay here because it's a basic human right and how much you campaign on the par-ticular vulnerabilities of that person' (lines 7-10). In this sense, Hayley evaluates the same phenomenon problematised in the refuge literature (Judge, 2010; Pupavac, 2008; Tyler, 2006; among others) that a political argument for the right to safety, eco- nomic opportunities, free movement and so on is usurped by a welfare claim based on a limited (and exclusionary) notion of victimhood. Hayley is critical of this type of advocacy, as a lose-lose situation, 'you never win an anti-deportation campaign' (line 5). As she states in line 10, through an anecdote concerning a barrister, 'he realised how completely brutalised he'd been by the system ... when somebody once told him she'd been raped and his first response was "oh good I can use that", (lines 12 and 13). Hayley formulates the contingency of suffering (particularly rape) as a marker of legitimacy as 'brutal'. It is not only the client who is brutalised by being raped but also the advocate who is stripped of their humanity by the system, seeing rape simply in terms of its legalistic value.

Hayley is not only critical of the 'system' which brutalises people but also the victimi- sation of asylum seekers/refugees by advocates; she is calling out this tendency in advo- cacy work. Hayley, as a lay analyst, is acknowledging and criticising the extent to which 
systemic hostility and mainstream policy towards asylum seekers/refugees frames and necessitates certain (dis-empowering) responses from advocates.

Here, orientation to the activity occasioned pair 'victim' and 'perpetrator' extends the reworking further than RAN achieved in Extract 1. The 'system' is hearable as the per- petrator of brutality and asylum seekers/refugees (and in this case the advocate too) are the victims of these activities. This victimhood foregrounds the brutality of the system not the vulnerability of the client. The reliance on detailed exposures of suffering and harm is explicitly challenged.

The following extract is taken from my interview with Sally, a volunteer with ASWU. Sally is a freelance film-maker who made a film following members of the group as they prepared for and performed a play about being an asylum seeking woman. Here, she talks about the ways in which the filming allowed her to 'show a more gentle portrayal of people's lives' (lines 1 and 2):

\section{Extract 5}

1 S: But I think the films stands alone outside of anthropology even to show a more

2 gentle portrayal of people's lives and um:: at the film screening um:: a visiting

3 commentator asked me why I hadn't included any of um:: any kind of politicians

4 remarks or any archive material about to- to contextualise it more or to- rather than

5 just saying these people are in the system, to say they, this systems awful and to

6 make all these statements um: and I guess what my response to that was basically

7 we get that all the time and if I had if I had- the ability to make a film then who I

8 was going to worry about interviewing wouldn't be the people who get

9 interviewed all the time and state their cases quite clearly um:: I think that that's

10 what- what I felt was important about the uh:: the work that wethat I've done

11 with um:: with Asylum Seeking Women Unite really and some other groups 
12 subsequently; was this idea that people have something to say about lots of things

13 they're people who- you know who have something to say about life, um::

14 about their children about their families they're not just there to talk about

15 themselves as asylum seekers or migrants or Diaspora they've got lives that

16 they're living now that they want to talk to you about. They want to talk to you

17 about the price of food, anyway, not just because they're restricted to what they

18 buy but because that's how- that's a conversation so I think that's really im-

19 important that that's emphasised. So I was very happy to keep working with

20 Asylum Seeking Women Unite after I finished the film on the play project.

Sally makes explicit that she is not interested in creating a platform for those whose voices dominate discourses on asylum seekers; rather, Sally wants to talk about asylum seeking women, and let asylum seeking women speak for themselves. Who are asylum seeking women in this extract? ASWU women are 'people [who] have something to say about lots of things' (line 12). This immediately pierces two conventions by which asy- lum seekers are limited in the media; asylum seekers have a voice, and they have a voice about many things - not just the limited tropes performed by more powerful speakers in the network. Sally goes further than making an argument for the inclusion of asylum seekers/refugee voices, she challenges the way that these voices are framed: 'they're not just there to talk about themselves as asylum seekers or migrants or Diaspora they've got lives that they're living now that they want to talk to you about' (lines 14-16). 
These are not the 'mute victims' (Malkki, 1996); rather, they are women with 'some- thing to say about life' (lines 9 and 10). Sally makes the women ordinary; they are women with children and families, who have everyday concerns. 'They want to talk to you about the price offood, anyway, not just because they're restricted to what they buy but because that's how-that's a conversation' (lines 16-18). These activities predicate the category 'ordinary women'; they are mothers with domestic concerns. Sally manages a discursive re-contextualisation of the women she works with; in doing so, she orients her talk against some of the common tropes of refugee representation discussed earlier. These are not villains or victims; these are ordinary women with ordinary concerns, and significant discursive labour is invested in foregrounding this ordinariness. Sally's project is not just to present the voices of women asylum seekers but to foreground their agency inclusive of and yet beyond asylum seeking.

Clearly, the ordinariness that Sally asserts here does not achieve the same status for ASWU women as the campaign leaflet for Sara, produced by the same organisation (Extract 3 ). While the ordinariness here negates 'mute' victimhood, the ordinariness in 'Extract 3' foregrounds Sara's innocence and makes her hearable as a victim of rape and persecution.

\section{Refugee voices}

This extract is taken from an interview I conducted with two female members of the self- advocacy group ASWU. Both women are members of the group's management commit- tee. In this part of the interview, the women are talking about the play they were involved with (written by Lisa), through which they wanted to tell people what it is really like to be an asylum seeker:

\section{Extract 6}

1 L: it definitely is starting to get that message across to people anyway (..) and I

2 guess that is that one of the aims of ASWU as well really 'cos you know like you

3 said there's not just been the play but books and poems and workshops

4 Li: yeah

5 L: and (...) it really is about telling people (..) what it- what it's really like

6 D: yeah, just to tell people who asylum seekers really are, because 
we are human

$7 \quad$ like anybody else

7 L: sure

8 D: we feel pain and you kn; ow as she's saying we were (..) people before we

9 came to this country where they always say "Oh $(-)$ so so so" we, so we just

10 want to tell people that we are we, we- are still human, we are who we are, no

11 matter what they say we still remain what we know we are

12 L: yeah

13 (pause)

14 Li: and we are strong, we are strong, because people just listening to it (..) they are

15 depressed

16 L: hmm::

17 Li: then imagine this is our really life this is what [we are going through

18 D: mm:: what we are going through 
In the discussion, Lisa and Dorothy emphasise and orient their talk against the mis- leading representations of refugees in the media; they want to 'tell people what it's really like' (line 5). In doing so, they acknowledge the hostile theme that asylum seekers are 'not human' and assert their ordinariness: 'we are human like anybody else' (lines 6 and 7). Yes, they suffer and live lives that people may find it hard to imagine (lines 16 and 17), and they make this suffering relevant to their narratives. However, this orientation to suffering foregrounds their strength as women; despite the pain and depression they experience, they are strong: 'we are strong, we are strong' (line 14). The women assert their strength, an image of the female asylum seeker which is uncommon in both hostile and advocacy discourse (Judge, 2010).

Lisa and Dorothy orient their talk against the (unnamed) hostiles (indexed as 'they', line 10), who silence or manipulate the voices/identities of asylum seekers: 'we are who we are, no matter what they say, we still remain what we know we are' (lines 10 and 11). This formu- lation bears a stark contrast to the usual treatment of asylum seeker/refugee voices; they are often missing (Leudar et al., 2008) or articulated via advocates (Judge, 2010). Here, the women assert primarily their ordinariness, then their strength and challenge those that mis- represent them through stories that 'depress' the listener or work to dehumanise them. By challenging the hostility and dominant representations of refugees with their own voice, they position themselves as authoritative and powerful participants in the dialogical network.

In the following extract, we hear the voice of Elizabeth, a member of ASWU and attendee at RAN and ILAM. At the time of the interview, she was awaiting a decision on her asylum claim and was keen to voice her complaint about the UK Visas and Immigration 'voucher' system:

\section{Extract 7}

1 E: so one other thing that I wanted to- to mention about the support, do you know

2 at the moment, [-], I have

3 no support from immigration

4 L: right $\mathrm{OK}$

5 E: I have no house from immigration, I'm living with my boyfriend

6 L: OK

$7 \quad \mathrm{~K}$ : my partner, I have

no support 8 L: $\mathrm{mm}:$ :

9 E: when I used to use the voucher before, because I was arrested 
again in 2009,

10 first time I was arrested in 2006 I did three months in detention and came out but

11 in 2009 I was arrested again. You know myself I do not have children. But I

12 have two children I'm taking care of

13 L: OK

14 E: my sister died

15 L: right $\mathrm{OK}$ [sorry

16 E: they live in $\mathrm{xxxx}$ ] they need to go to school to study, I had no money to support

17 them

18 L: OK

19 E: the voucher I used to receive couldn't help me to support

20 L: of course

21 E: because the voucher I can't have the cash with it

22 L: yeah, you can only [use it in certain places 
23 E: I can't because for myself I can't it is very very hard, very very hard, at the

24 moment I'm telling you these kids they do not attend the school and they are girls,

25 what about their future?

26 L: right, are they in the $\mathrm{xxxx}$ still?

27 E: they're in the Xxxx very very sad (...) no one to take care of them at the

28 moment, I have no financial support for them, because of myself I am sorry. [It

29 is very very difficult.

30 L: right yeah]

31 E: you know, I can say, my experience here is sometimes bad and good

32 L: mm:: hmm:: yeah

Elizabeth is hearable as incumbent of various categories here; she is a victim of unjust immigration policies and a villain; she was arrested in 2006 and 2009. Primarily though, she is a complainant. The literature has identified that asylum seekers and migrants are hearable as victims or villains (Crawley et al., 2016; Van Dijk, 2000) and that in order to rebut hostility, passivity and innocence must be foregrounded (Judge, 2010; Malkki, 1996; Van Dijk, 2000). Elizabeth, while presenting her need vicariously through the needs of the children, making it hearable as valid, does not lay claim to innocence or passivity, of herself or the children. She is a resourceful woman who has found some- where to live despite being made destitute by the immigration system. It is this resource- fulness that is foregrounded, not her suffering at the hands of policy. The interrogative 'what about their future?' (line 25) positions Elizabeth as morally responsible and calls into question the morality of the immigration system. Elizabeth is a woman with a com- plaint about her treatment by the immigration system that does not require validation through performative innocence or suffering; despite her situation, and the actions of the immigration system, her experience in the United Kingdom is sometimes bad and some- times good. This bears a stark contrast to the extreme case formulations focused on by the organisations in their publicity materials.

Importantly, this narrative is multidimensional; Elizabeth does not negotiate for herself the identity 'pure victim'; she is an agentive actor with a complaint to make and opinions on the future of her sister's children. She is a carer in an environment that jeopardises her ability to care. She is not simply hungry and homeless. Although the vouchers she receives put huge 
limits on her financially 'the voucher I used to receive couldn't help me to support [the children]' (line 19), there is depth to her complaint; she can only spend them in certain places, and she cannot support her sister's children. What is at stake here is more than her basic welfare, it is her civil right to autonomy and the future of the children.

These other and self-presentations are organised 'thematically' and in orientation to exophoric circumstances that can also be said to be thematically organised. Hostility is not always passively received or internalised by the informants, but it is challenged and denied. In Elizabeth's talk, significant 'discursive labour' (Kirkwood et al., 2013) is not exerted in order to rebut hostility or manage a biographical contrast; the focus is on asserting a complaint and a demand - this activity positions Elizabeth as someone's whose voice is not only legitimate but also inexplicably powerful. Where hostility enters this talk, the denials do not rely on orientations to 'victimhood' but manifest via negotia- tions of ordinariness or as complaints against common tropes of refugee representation. Suffering is formulated as the ground against which personal and collective strength and a challenge to the fairness of the asylum system are foregrounded. 


\section{Discussion}

This article explored how refugee advocates and refugees themselves manage hostility in their talk, specifically how this hostility is managed through orientation to the category 'victim', where the identifies of refugees are concerned. To do so, case studies from the public facing talk of four advocacy organisations, as well as the 'internal' talk of their staff, volunteers and beneficiaries is examined. This allows insight into differing aspects of the organisation's talk and allows analysis of how orientation to the victim category is managed and altered across the dialogical network.

This article applied a discourse analytic approach, sensitive to how members of the dialogical network make hostile and sympathetic voices relevant features of their local talk and manage categorisations of refugees in often tacit ways. These orientations are at times explicit, using quotes and direct reference to exophoric voices. This is evident in Extract 1, with the use of reported speech and in Extracts 5 and 6, which invoke the voice of those who reduce people's experience to 'asylum seeker' or 'diaspora', rather than their experiences as women or humans in general. These hostile and sympathetic themes of refugee representation are also tacitly acknowledged, as in Extract 4 where Hayley asks 'how much do you campaign on the vulnerabilities of that person' orienting her talk to the victimisation of refugees by advocates in response to a 'brutal' immigration sys- tem. Similarly, in Extracts 2 and 3, the discursive labour exercised in constructing Josephine and Sara as innocent, and therefore hearable victims, manifests a tacit acknowl- edgement of the disbelief that is characteristic of hostile voices (see Extract 1). Furthermore, it evidences the internalisation of the 'victim' category and its characteris- tics, specifically, the foregrounding of infancy (as in Josephine's story, Judge, 2010) and the resort to an epistemic medical authority that demands physical evidence of suffering, over personal accounts or expressions (as in Sara's story, Pupavac, 2008).

Advocate and refugee members of the organisations act as lay analysts, recruiting the words of the organisations, (either tacitly or otherwise) and directly challenging the assumptions being made. In each of the extracts, the dehumanisation and victimisation of refugees is emphasised. Hayley calls into question the reliance of 'rape' as a marker of authenticity and positions the immigration system as brutal in its deference to physical evidence of suffering, a tactic also adopted by ASWU in their construction of Sara's story. Sally, in contrast, formulates the members of ASWU as women, first and foremost, with something to say that extends beyond their experience as asylum seekers or dias- pora, orienting against the 
reporting on asylum issues that 'leach out' individual identi- ties (Malkki, 1996: 378). Similarly Dorothy and Lisa dispute those who do not see them as human, and share instead their experience of strength and suffering, of good and bad, as is also the case in Elizabeth's narrative.

Of analytic and practical significance is how and when people become victims; in the publicity materials, we hear about the victimisation of people before coming to the United Kingdom - an action orientation of this is to provide an account, a justification of why the person came to the United Kingdom to seek refuge. Their lack of agency and the degree of their suffering and innocence marks their legitimacy; they had no choice, and they had to come. This rebuts the hostility articulated in Extract 1 that asylum seekers are criminals who came to the United Kingdom to 'rape and pillage' the country - they are not villains they are profoundly hearable victims (Crawley et al., 2016). In 
contrast, victimhood in the talk of advocates and refugees is formulated in the context of oppression and exclusion by the immigration system. Refugees become victims in a more temporal, contextualised way that foregrounds not their vulnerability but their strength and ordinariness in the face of oppressive policies. This politicises (by indexing the context) and de-naturalises (by humanising and making temporal) the suffering of refugees.

An implication of these observations is that refugee advocates restrict their texts and communications (the publicity materials) to a humanitarian message, characterised by lim- ited markers of refugee legitimacy primarily based on suffering. They do this while their members acknowledge and challenge the inherently exclusionary logics which are being left un-interrogated on an organisational level. These voices tell us

something that is not heara- ble unless we seek to centre the voices of those involved in and receiving advocacy and to analyse the polyphony of voices that exist within this complex and contested area of work. For advocates and refugee informants, speaking of the hardship refugees face in the context of brutal marginalisation by the state, the notion of victimisation means some- thing altogether different. As Sacks (1979) pointed out, non-compliance with a category, and its usage, is an act of resistance. In this sense, acts of resistance are rife within con- temporary advocacy organisations, at the level of internal talk. In contrast to the publicity materials, which provide the 'public face' of the organisations, advocate and refugee members focus their narratives on the source of the hostility, more so than its conse- quences. This allows the victimisation of refugees to take on a temporal, contextual form. They also explicitly challenge attempts at dehumanising refugees and stripping them of their voices - they want to provide a platform for refugees to tell their own stories as human beings, with something to say.

Importantly, advocates and refugees as members of these organisations and of the dia- logical network call out problems with the current immigration system and the systems of support and suggest new ways forward. These include giving voice to refugees as experts of their own experience, to tell their stories in a way that speaks to their humanity (Lisa and Dorothy), ordinariness (Sally) and strength (Lisa and Dorothy) and does not defer to brutal descriptions of suffering (Hayley) but allows for the 'good and bad' (Elizabeth) that makes up people's lives. Hayley's narrative, much like the calls from the literature dis- cussed in the introduction, asks for asylum cases not to rely solely on the vulnerabilities 
of an individual, which raises the bar of what it means to be legitimately hearable as a refugee (Pupavac, 2008; Tyler, 2006). If we are to take heed of this advice, we must endeavour to centre the voices of refugees, in an unedited way, away from a humanitarian gaze, that lets people be humans in all the idiosyncratic and ordinary ways that they are. It has been argued that 'showing the normalcy of migrants' everyday lives may provide a basis for greater social solidarity'. It allows us to recognise ourselves in others, instead of only recognising suffering in 'others' (Crawley et al., 2016: 6, see also Turton, 2003).

Elizabeth stresses the issue of housing, vouchers and destitution; the vouchers are not an adequate form of support nor do they allow her to look after the children; Sally also makes the issue of vouchers relevant. These vouchers are given to asylum seekers on Section 4 support in the form of an 'Azure' card and can only be used in certain shops and cannot be exchanged for cash-making bus travel impossible. This is an important issue for people in the asylum process and presents an ask/demand to the Home Office to provide support that is more suitable to the needs of asylum seekers and their families. Elizabeth 
is now destitute and is not in receipt of this most basic and minimal form of support, sig- nificantly though the suffering caused by destitution is not foregrounded, it is the prob- lems that cause destitution that are brought into focus. More could be done to explore a role for advocacy in focusing attention on the situations that create suffering and the exclusion of others and thus making demands to rectify poor policy and practice, which can negate a reliance on the graphic victimisation of refugees.

Advocates 'on the ground' and those with experiential knowledge of the asylum sys- tem are already 'working at the limits of the available lexicon, including rights dis-courses, while simultaneously contesting the "regimes within which the terms of recognisability take place", (Tyler, 2006: 199). Critical work needs to go beyond the naming of problems and must indeed explore the tensions and cracks that already exist, in order to conceptualise and promote new ways of talking and doing.

Tyler (2006) advocates an approach that values 'listening', placing the emphasis on the 'bodies and constituencies from whose suffering such accounts takes its cue' (p. 200). The women interviewed for this study have complaints to make about their treatment by the British state and public; as advocates with or without this experience, we must centre these narratives in our work. This article aimed to create a vital space for people seeking refuge to use their voice and to take control of their narrative, their identity and their struggle. However, as Nyers (2006) contests, " Giving" the refugee a voice is not just a practical problem of providing opportunities, especially when the hierarchies giver- receiver, helpervictim, listener-crier are left untouched' (p. 124). The category work negotiated by refugee informants here began to rearrange the components of the helping relationship, centring the experience, voice and strength of asylum seekers/refugees and de-centring the objectives of helping organisations. As academics and advocates, we will learn a lot more about contemporary refugee advocacy and implications for practice, when we listen, without translating, reducing and speaking for those most affected by borders. These voices are important cracks (Holloway, 2010) that break the relations of liberal reformist practices and point to new ways forward for an advocacy of solidarity between agentive actors, rather than a humanitarianism between speaker and spoken for.

\section{Acknowledgements}

I would like to thank all of the organisations and people who took part in this research project and whose insights and ideas are invaluable for this article and my development as a practi- tioner and researcher. Thank you 
to Ivan Leudar for his supervision of my doctoral thesis and this article and to the reviewers for their helpful feedback and comments.

\section{Declaration of conflicting interests}

The author(s) declared no potential conflicts of interest with respect to the research, authorship, and/or publication of this article.

\section{Funding}

The author(s) disclosed receipt of the following financial support for the research, authorship, and/ or publication of this article: This work was supported by the Economic and Social Research Council under grant number ES/I903445/1. 


\section{References}

Anscombe GEM (1957) Intention. Oxford: Blackwell.

Antaki C and Leudar I (2001) Recruiting the record: Using opponents' exact words in parliamen- tary argumentation. Text 21: 467-488.

Bates D (2017) The "red door" controversy - Middlesbrough's asylum seekers and the discursive politics of racism. Journal of Community \& Applied Social Psychology 27: 126-136.

Bloch A and Schuster L (2002) Asylum and welfare: Contemporary debates. Critical Social Policy

22(3): 393-414.

Crawley H McMahon S and Jones K (2016) Victims and villains: migrant voices in the British media, Centre for Trust, Peace and Social Relations. Available at: https://curve.coventry. ac.uk/open/file/3ff683bc-b508-40d6-86e5-

422e955c5960/1/Victims\%20and\%20Villains__ Digital.pdf (accessed 1 November 2017).

Edwards D and Potter J (1992) Discursive Psychology. London: SAGE. Garfinkel H (1967) Studies in Ethnomethodology. Englewood Cliffs, NJ: Prentice Hall. Goodman S (2005) Constructing asylum seeking families. Critical Approaches to Discourse

Analysis across Disciplines 1: 36-50.

Goodman S and Speer SA (2007) Category use in the construction of asylum seekers. Critical Discourse Studies 4(2): 165-185.

Goodman S, Sirriyeh A and McMahon S (2017) The evolving (re)categorisations of refugees throughout the 'refugee/migrant crisis'. Journal of Community \& Applied Social Psychology 27: 105-114.

Harrell-Bond BE (1986) Imposing Aid: Emergency Assistance to Refugees. Oxford: Oxford University Press.

Hoijer B (2004) The discourse of global compassion: The audience and media reporting of human suffering. Media, Culture and Society 26(4): 513-531.

Hester S and Eglin P (1997) Culture in Action: Studies in Membership Categorisation Analysis.

Washington, DC: University Press of America.

Holloway J (2010) Crack Capitalism. London: Pluto Press.

ICRC (1992) Code of Conduct for the International Red Cross and Red

Crescent Movement and Non-Governmental Organisations (NGOs) in Disaster Relief. Available at: http://www.icrc. org/eng/assets/files/publications/icrc-002-1067.pdf (accessed June 2012). 
Judge R (2010) Refugee advocacy and the bio-politics of asylum in Britain: The precarious posi- tion of young male asylum seekers and refugees. Working paper series no. 60. Refugee Studies Centre. Available at: https://www.rsc.ox.ac.uk/files/files-1/wp60-refugeeadvocacy- biopolitics-asylum-britain-2010.pdf

Kirkwood S (2017) The humanisation of refugees: A discourse analysis of UK parliamentary debates on the European refugee 'crisis'. Journal of Community \& Applied Social Psychology 27: 115-125.

Kirkwood S, McKinlay A and McVittie C (2013) The mutually constitutive relationship between place and identity: The role f placeidentity in discourse on asylum seekers and refugees. Journal of Community \& Applied Social Psychology 23: 453-465.

Lee J (1984) Innocent victims and evil-doers. Women's Studies International Forum 7(1): 69-83. Leudar I and Nekvapil J (2004) Media dialogical networks and political argumentation. Journal of

Language and Politics 3: 247-266.

Leudar I, Marsland V and Nekvapil J (2004) On membership categorisation: 'Us', 'them' and 'doing violence' in political discourse. Discourse \& Society 15: 243-266.

Leudar I and Antaki C (1996) Discourse participation, reported speech and research practices in social psychology. Theory and Psychology 6: 5-29. 
Leudar I, Nekvapil J, Hayes J, et al. (2008) Hostility themes in media, community and refugee narratives. Discourse \& Society 19(2): 187221.

Lynn N and Lea S (2003) A phantom menace and the new Apartheid: The social construction of asylum-seekers in the United Kingdom. Discourse \& Society 14(4): 425-452.

Malkki L (1996) Speechless emissaries: Refugees, humanitarianism and dehistoricization. Cultural Anthropology 11(3): 377-404.

Masocha S (2014) We do the best we can: Accounting practices in social work discourses of asylum seekers. British Journal of Social Work 44(6): 1621-1636.

Nightingale A, Quayle M and Muldoon O (2017) "It's just heart breaking": Doing inclusive politi- cal solidarity or ambivalent paternalism through sympathetic discourse within the "refugee crisis" debate. Journal of Community \& Applied Social Psychology 27: 137-146.

Nekvapil J and Leudar I (2006) Sequencing in media dialogical networks. Ethnographic Studies

8: 30-43.

Nyers P (2006) Rethinking Refugees: Beyond States of Emergency. London: Routledge. Pomerantz A (1986) Extreme case formulations: A way of legitimizing claims. Human Studies

9(2-3): 219-229.

Pupavac V (2006) Refugees in the 'Sick Role': Stereotyping Refugees and

Eroding Refugee Rights. Policy Development and Evaluation Service,

UNHCR. Available at: http://www.unhcr. org/44e198712.pdf (accessed 25 August 2011).

Pupavac V (2008) Refugee advocacy, traumatic representations and political disenchantment.

Government and Opposition 43(2): 270-292.

Sacks H (1979) Hotrodder: A revolutionary category. In: Psathas G (ed.)

Everyday Language: Studies in Ethnomethodology. New York:

Irvington Press, pp. 7-14.

Sales R (2002) The deserving and the undeserving. Critical Social Policy 22(3): 456-478.

Santa Ana O (1999) 'Like an animal I was treated': Anti-immigrant

metaphor in us public dis- course. Discourse \& Society 10: 191-224.

Schegloff E (2000) On granularity. Annual Review of Sociology 26: 715720 .

Steimel S (2010) Refugees as people: The portrayal of refugees in American human interest sto- ries. Journal of Refugee Studies 1-16. 
Turton D (2003) Conceptualising forced migration. Working paper 12. Oxford: Refugee Studies Centre, University of Oxford.

Tyler I (2006) Welcome to Britain: The cultural politics of asylum. European Journal of Cultural Studies 9(2): 185-202.

Van Dijk TA (2000) On the analysis of parliamentary debates on immigration. In: Reisigl $\mathrm{M}$ and Wodak $\mathrm{R}$ (eds) The Semiotics of Racism: Approaches in Critical Discourse Analysis. Vienna: Passagen Verlag, pp. 85-104.

Wengraf T (2001) Qualitative Research Interviewing: Biographic Narratives and Semi-Structured Methods. London: SAGE.

Zhang C and Schwartz N (2011) How and why 1 year differs from 365 days: A conversational logic analysis of inferences from the granularity of quantitative expressions. Journal of Consumer Research 39(2): 248-259.

\section{Author biography}

Lauren Elizabeth Wroe completed her $\mathrm{PhD}$ at the University of Manchester in 2013, under the supervision of Professor Ivan Leudar. Since completing this work, she has qualified as a social worker and has worked in a range of charitable and statutory organisations with children and adults at risk of exploitation and trafficking. She is particularly interested in the language and practice of refugee advocacy as a practice of solidarity beyond charity and is a co-founder of the social work organisation 'Social Workers Without Borders'. 